
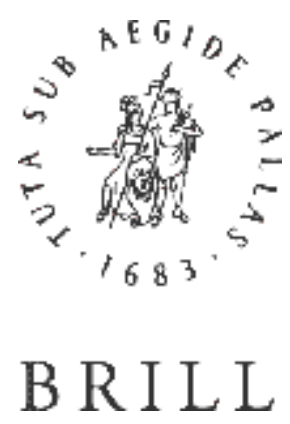

Jan Vos (1610-1667), de schilderkunst en de Amsterdamse regenten

Author(s): Nina Geerdink

Source: Oud Holland, Vol. 127, No. 2/3 (2014), pp. 93-108

Published by: Brill

Stable URL: https://www.jstor.org/stable/24767967

Accessed: 21-10-2019 07:52 UTC

\title{
REFERENCES
}

Linked references are available on JSTOR for this article: https://www.jstor.org/stable/24767967?seq=1\&cid=pdf-reference\#references_tab_contents You may need to log in to JSTOR to access the linked references.

JSTOR is a not-for-profit service that helps scholars, researchers, and students discover, use, and build upon a wide range of content in a trusted digital archive. We use information technology and tools to increase productivity and facilitate new forms of scholarship. For more information about JSTOR, please contact support@jstor.org.

Your use of the JSTOR archive indicates your acceptance of the Terms \& Conditions of Use, available at https://about.jstor.org/terms

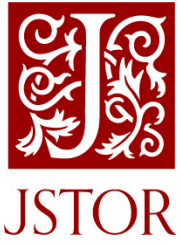




\section{Jan Vos (1610-1667), de schilderkunst en de Amsterdamse regenten}

In 1667 deed de Amsterdamse dichter Jan Vos de toneelwereld versteld staan met de opvoering van de gruweltragedie Medea, waarin hij alles uit de kast haalde om te tonen wat de pas verbouwde Amsterdamse schouwburg, waarvan hij een van de bestuurders was, vermocht. Hij liet de publicatie van het stuk voorafgaan door een vooruitstrevend betoog voor een selectiever gebruik van klassieke voorbeelden in het Nederlandse toneel. De meeste aandacht genereerde hij echter met zijn uitspraak ' $t$ zien gaat voor ' $t$ zeggen', een motto dat nog steeds bekender is dan welk ander onderdeel van Vos' werk ook.

Het is onder andere vanwege dit motto dat Vos bekend is komen te staan als 'man van het beeld'. Dat Vos een opmerkelijke voorliefde had voor de visuele kunsten blijkt verder uit zijn 340 gedichten naar aanleiding van schilderijen en andere afbeeldingen en uit het lange lofdicht over de schilderkunst dat hij schreef ter gelegenheid van de jaarlijkse Lucasviering van het Amsterdamse schildersgilde in 1654 . Zijn stijl, zowel in toneelstukken als in gedichten, is bovendien zeer beeldend.

Vos' voorkeur voor het beeld is op verschillende manieren uitgelegd. Vos zou intensieve vriendschappen onderhouden hebben met de schilders die hij als glazenmaker en als schouwburghoofd ontmoette - glazenmakers waren aangesloten bij hetzelfde $\mathrm{St}$. Lucasgilde en in de schouwburg speelden schilders een actieve rol bij de vervaardiging van decors. ${ }^{.}$Daarnaast is de prominente rol van het beeld in Vos' poëtica in verband gebracht met diens katholicisme: als katholiek zou Vos zich met zijn aandacht voor het beeld en de kracht die hij daaraan toekende, afzetten tegen de beeldvijandelijke calvinisten. ${ }^{2}$

Deze verklaringen kunnen in meer of mindere mate bijgedragen hebben aan Vos' aandacht voor het beeld, maar het lijkt erop dat Vos' patronagerelatie met de Amsterdamse elite doorslaggevend geweest is. Gary Schwartz heeft eerder betoogd dat juist de regenten die het in Amsterdam rond het midden van de zeventiende eeuw voor het zeggen hadden, verantwoordelijk waren voor de opvallende bloei van bimediale genres in die tijd. ${ }^{3}$ Wie het werk van Vos, door Jacob Lescaille verzameld in twee delen Alle de gedichten, ${ }^{4}$ vanuit dit perspectief beschouwt, moet concluderen dat zijn voorkeur voor de beeldende kunsten en het beeldende gerelateerd is aan de patronagerelatie die hij onderhield met de Amsterdamse stadsregenten. ${ }^{5}$ Vos was een van de dichters die de onofficiele status van stadsdichter bemachtigden. Hij toonde zijn betrokkenheid door de stad, de bestuurders en hun beleid te prijzen in talloze gedichten. De rijke en machtige stadsregenten stimuleerden dit door op te treden als patronen en Vos op tal van manieren te ondersteunen. ${ }^{6}$

Dat het de voorliefde van de regenten is die maakte dat Vos in zijn werk zoveel aandacht heeft voor het beeld, blijkt in de eerste plaats uit het feit dat ze hem regelmatig vroegen 'vertoningen' (tableaux vivants, levende beelden gecombineerd met gedichtjes) te maken ter gelegenheid van stedelijke festiviteiten, maar ook Vos' gedichten die op het eerste oog alles met schilders en de schilderkunst te maken lijken te hebben, blijken een belangrijke rol gespeeld te hebben in de patronagerelatie tussen Vos en de regenten. 
Ik laat dat in dit artikel zien door een analyse van Vos' portretgedichten, zijn beeldgedichten en het lange gedicht Strydt tusschen de Doodt en Natuur, ofZeege der Schilderkunst (1654). In de laatste paragraaf besteed ik aandacht aan het handjevol gedichten waarin Vos zich tot individuele schilders richtte.

\section{Portretgedichten}

Vos schreef zo'n 160 portretgedichten.7 Hieronder zijn gedichten naar aanleiding van portretten (schilderijen of gravures) van oorlogshelden, dichters, geleerden, internationale politieke kopstukken, en een klein aantal priesters. Meer dan de helft gaat echter over portretten van leden van de Amsterdamse elite. Het is evident dat Vos deze gedichten schreef ter ere van de geportretteerden en niet om de vervaardigers van de portretten te

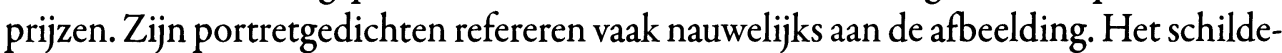
rij of de gravure wordt af en toe genoemd in de titel, soms in combinatie met de naam (of initialen) van de schilder of graveur. Vaker blijkt alleen uit de eerste regel dat het om een beeldgedicht gaat omdat deze conventioneel begint met 'Dus ziet men...', 'Dus toont de kunst...' of een vergelijkbare uitdrukking. De rest van het gedicht gaat alleen over de geportretteerde. Vos beschrijft diens innerlijke en uiterlijke deugden, waarbij hij vaak verwijst naar de betekenis van de geportretteerde voor de Amsterdamse samenleving. Het gaat dus in feite om lofdichten die aan kracht winnen door de verwijzing naar portretten, die immers beschouwd werden als krachtige middelen voor de zelfrepresentatie van de regenten als rijke kunstminnaars en verantwoordelijke, machtige regeerders. ${ }^{8}$

$\mathrm{Nu}$ was het gebruikelijk in het genre van het portretgedicht om vooral nadruk te leggen op de lof van de geportretteerde, ${ }^{9}$ maar Vos drijt dit opvallend ver door. De lof in portretgedichten werd traditioneel vormgegeven onder verwijzing naar de zogenaamde paragone: de speelse strijd tussen de zusterkunsten dichtkunst en schilderkunst. Portretgedichten gingen vaak over de vraag welke van de twee kunsten er het best in slaagde de werkelijkheid weer te geven en dichters concludeerden uiteraard meestal dat de poëzie daar beter in slaagde: een schilderij was immers niet in staat de stem van de geportretteerde weer te geven, en dat werd beschouwd als een belangrijke tekortkoming. ${ }^{10}$ Het zou voor de hand liggen dat ook Vos dit motief gebruikte in zijn portretgedichten, maar niets is minder waar. Vos gebruikte wel het motief van rivaliteit, maar bij hem waren het meestal niet dichtkunst en schilderkunst die tegenover elkaar stonden, maar de roem van de geportretteerden en de schilderkunst. Vos stelde dat de geportretteerde regenten hun portretten eigenlijk niet nodig hadden, omdat hun deugden zo groot waren dat hun faam vanzelf ver genoeg reikte. Ter illustratie citeer ik een paar regels uit een portretgedicht over burgemeester Cornelis de Graeff(1599-1664):

Als Graaf begraaven is zal hy zich dus vertoogen:

Maar' $t$ brein dat hem Minerf, tot heil van Hollandt, gaf,

Dat zal men door't penseel van zyne Faam beoogen. ${ }^{.1}$

De schilder van het portret wordt niet genoemd en Vos maakt duidelijk dat diens werk ook niet van belang is, omdat De Graeff zijn eigen faam schildert. Vos eigent zich het conventionele paragone-thema dus toe en past het aan om de roem van de geportretteerden te onderstrepen - in plaats van de roem van dicht- of schilderkunst.

Ook als Vos in portretgedichten bij wijze van uitzondering wél aandacht besteedde aan de zusterkunsten, was dat niet om een van de twee de hemel in te prijzen, maar om de lof van de geportretteerde extra kracht bij te zetten. De verwijzing diende dan om te onderstrepen dat de geportretteerde een liefhebber van de kunsten was, zoals bijvoorbeeld in het gedicht bij het portret van Joan Uyttenbogaert (1608-1680), de ontvanger van Holland: 


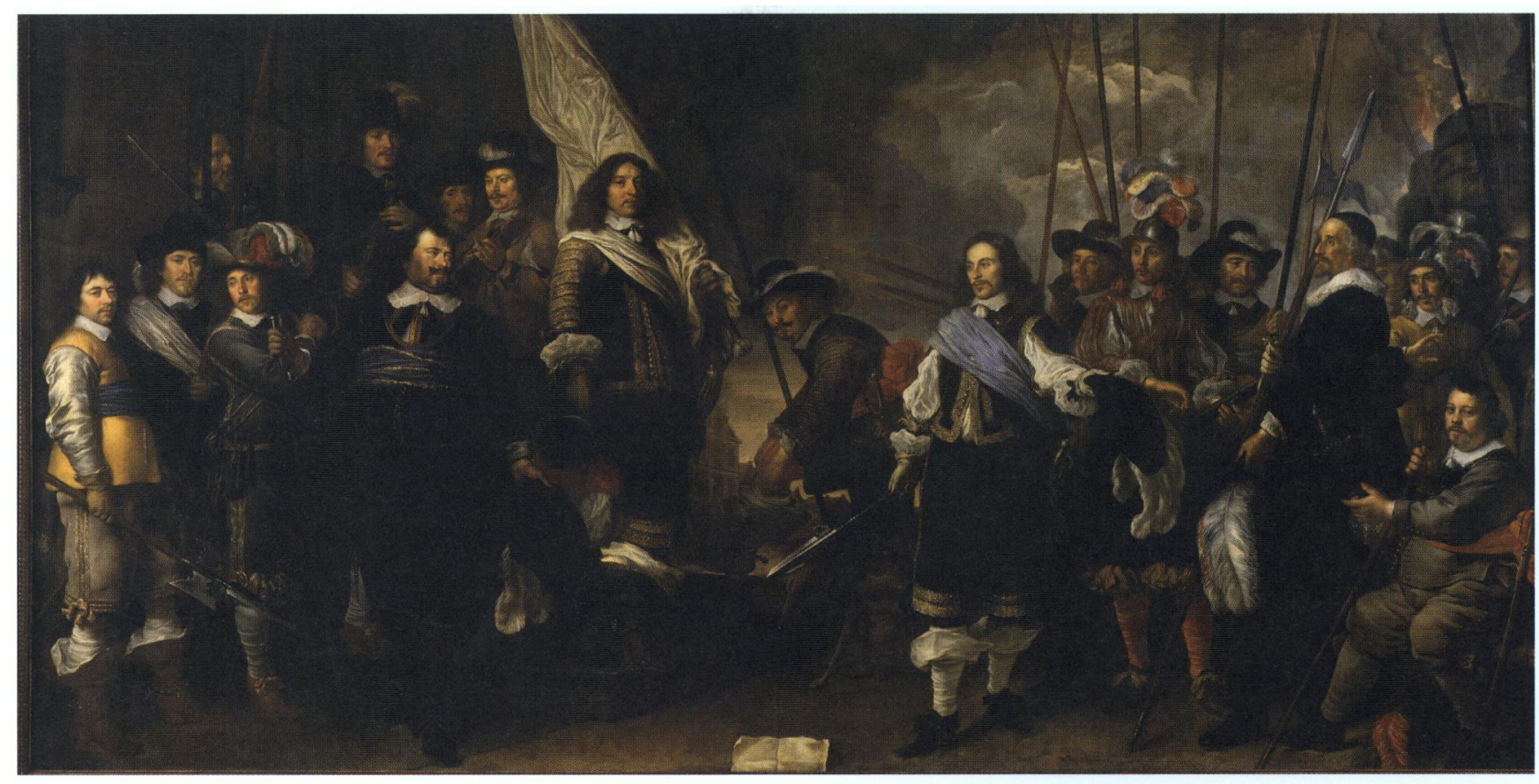

Govert Flinck, Schutters van de compagnie van kapitein loan Huydecoper en luitenant Frans van Waveren, 1648, doek, $256 \times 513 \mathrm{~cm}$. Amsterdam, Amsterdam Museum, inv.nr. SA 7318.

De Dicht- en Schilderkunst, twee zusters, die zijn lust Aanqueeken, weeten hem het oor en oog te streelen.

Wie schrander is bemint de pennen en penseelen. ${ }^{12}$

Dat Uyttenbogaert zijn oor en oog laat strelen door dicht- en schilderkunst, maakt hem blijkens de afsluitende sententie tot een verstandig man.

Behalve de ruim 80 portretgedichten die geschreven zijn naar aanleiding van portretten van belangrijke Amsterdammers, zijn ook andere portretgedichten in verband te brengen met Vos' campagne om Amsterdam en zijn regering te prijzen. Er is bijvoorbeeld een gedicht op het portret van Maria de Medici (1575-1642) dat Gerard van Honthorst (1592-1656) maakte ter gelegenheid van haar bezoek aan Amsterdam in 1638. Dit bezoek was erg belangrijk voor het zelfbewustzijn van de stad en het portret werd opgehangen in het stadhuis om de herinnering daaraan levend te houden. ${ }^{13}$ De lof op De Medici in Vos' gedicht is ook nog eens zo algemeen geldend geformuleerd dat de Amsterdamse regenten deze ook op zichzelf zouden kunnen betrekken.

Vos' portretgedichten werden verzameld in aparte afdelingen in Alle de gedichten. Soms waren ze eerder ook al gepubliceerd, en voor gedichten over regentenportretten geldt dat dit niet toevallig gebeurde in publicaties die nadrukkelijk een rol speelden in Vos' patronagerelatie met de regenten, omdat ze aan hen opgedragen werden en volledig in het teken stonden van het prijzen van de rijkdom en bloei van de stad. Een voorbeeld is Vos'Vergrooting van Amsterdam (1662), een lang allegorisch gedicht dat hij schreef naar aanleiding van de vierde uitleg van de stad waarmee in 1660 begonnen was. ${ }^{14} \mathrm{Het}$ gedicht werd opgedragen aan de vier burgemeesters van 1662, Cornelis de Graeff, Cornelis Witsen (1605-1669), Cornelis de Vlaming van Oudtshoorn (1613-1688) en Hendrik Hooft (1617-1678), en aan de twee thesauriers Gerard Schaep (1598-1666) en Joan van de Poll (1597-1678). 's Vos onderstreepte zijn betrokkenheid bij de stad en deze specifieke regenten door portretgedichten over hen achter het gedicht op te nemen.

Twee portretgedichten van Vos waren voor het publiek te lezen op de schilderijen naar aanleiding waarvan ze geschreven waren. Het gaat om schuttersstukken, schilderijen die een functie hadden die vergelijkbaar is met de vele lofdichten die Vos voor de regenten schreef: schuttersstukken hingen in publieke gebouwen zoals de Doelen en onderstreepten het belang en de deugden van de geportretteerden voor Amsterdam. ${ }^{16}$ Vos schreef'Korporaalschap van den Eed. Heer van Maarseveen' naar aanleiding van het 

schuttersmaaltijd in de Voetboog-o St. Jorisdoelen te Amsterdam ter viering van het sluiten van de Vrede van Munster, 18 juni 1648 , doek, $232 \times 547 \mathrm{~cm}$. Amsterdam, Rijksmuseum, inv.nr. SK-C-2. schuttersstuk dat Govert Flinck (1615-1660) makkte van het vendel van kapitein Joan Huydecoper sr. (1599-1661), een van Vos' belangrijkste patronen (afb. I). ${ }^{17}$ Huydecoper liet het schilderij maken ter ere van de Vrede van Munster in 1648 . Vos' gedicht staat op een stuk papier dat op de grond geschilderd is, midden op het schilderij, alsof het aan de voeten van het vendel ligt. In het gedicht worden Huydecoper en zijn vader geprezen om hun wijsheid en dapperheid. De afsluitende regel stelt dat het zwaard roest, maar niet rust, waarmee het verwijst naar de leden van het vendel, die hun zwaard omhoog houden, klaar om de stad te verdedigen tegen nieuwe gevaren. Een vergelijkbaar gedicht is geschilderd op het schuttersstuk van Cornelis Witsens vendel, gemaakt door Bartholomeus van der Helst (1613-1670) (afb. 2). Hier staat het gedicht op een vel dat aan de trommel bevestigd is. ${ }^{18}$

Opvallend, maar misschien niet zo verbazingwekkend, is dat Vos gedichten over de portretten van regentenvrouwen eigenlijk nooit apart publiceerde. Bijna elk portretgedicht voor een regent ging in Vos' verzamelwerk Alle de gedichten gepaard van een portretgedicht voor de echtgenote, en soms ook voor dochters. Deze gedichten leken op die voor de regenten zelf, hoewel Vos meer aandacht had voor de uiterlijke deugden en andere eigenschappen die als typisch 'vrouwelijk' beschouwd werden, zoals vroomheid en goede zorg voor het huishouden. ${ }^{19}$ Het feit dat de gedichten bij vrouwenportretten nauwelijks gepubliceerd werden, suggereert dat ze een rol speelden in intiemere kring dan de gedichten op mannenportretten, die in het prijzen van de manier waarop deze hun stedelijke taken uitvoerden natuurlijk ook nadrukkelijker een publieke taak hadden.

Sommige gedichten bij portretten van vrouwen wijzen nog eens extra op een intieme leeskring door de afwijkende speelse toon. Deze is bijvoorbeeld te herkennen in de portretgedichten die Vos schreef over de dochters van burgemeester Huydecoper sr. Het gedicht over Geertruidt Huydecoper (1634-1669) is illustratief. Met 24 regels is het veel te lang om als bijschrift te functioneren en de schoonheid van Geertruidt wordt zeer onconventioneel beschreven. Het narratieve gedicht speelt met de grenzen tussen schilderij en werkelijkheid door het voor te stellen alsof Cupido zichzelf verliefd heeft gemaakt op Geertruidt vanwege haar schoonheid, om vervolgens teleurgesteld te moeten constateren dat hij zichzelf verliefd heeft laten worden op een portret in plaats van op een echte vrouw:

Dit zyn, riep hy, gemaalde leeden.

O Maarseveen! kan 't kunstpenseel

Door koude verven harten blaaken?

Zoo is myn pyl, zeidt hy, onnut.

$\mathrm{Nu}$ leert het goodtje beelden maaken.

De Maalkunst strekt de Min tot schut. ${ }^{20}$

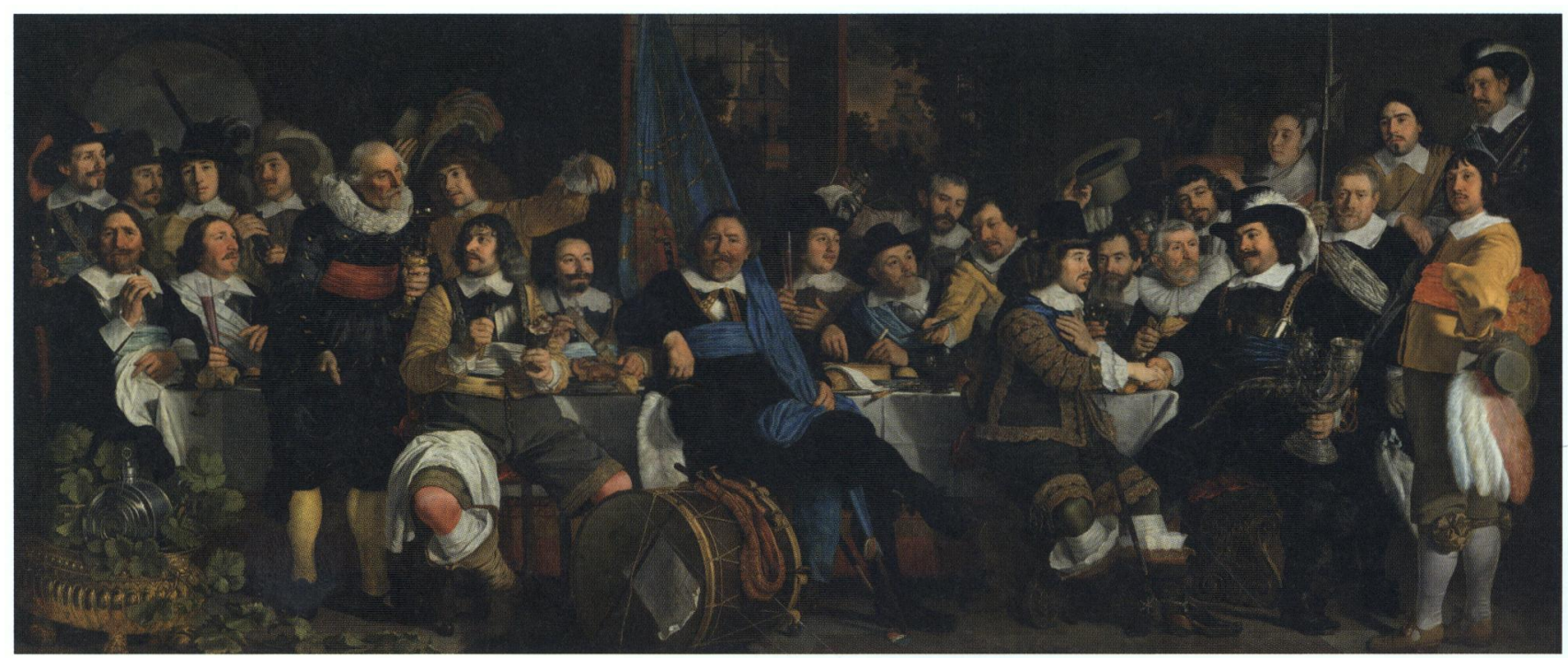


Cupido's ontdekking doet hem besluiten zijn pijl en boog weg te gooien: vanaf nu gebruikt hij schilderijen om mensen verliefd te maken. In tegenstelling tot wat gebruikelijk is in portretgedichten, onderstreept Vos hier dus de kracht van de schilderkunst. Dat is een motief dat ook in Vos' beeldgedichten naar aanleiding van historieschilderkunst een belangrijke rol speelt.

\section{Beeldgedichten}

Naast de 160 portretgedichten schreef Vos ook nog eens 180 gedichten naar aanleiding van andere afbeeldingen. ${ }^{21}$ De vervaardigers van de afbeeldingen worden in de gedichten meestal niet genoemd. Een enkele keer geeft Vos in de titel een naam, meestal van een in die tijd in Amsterdamse kringen beroemde schilder als Van der Helst, Flinck, Rubens of Titiaan, vaker geeft hij enkel initialen. Op basis van deze schildersinitialen en de onderwerpen van de bezongen schilderijen moet geconcludeerd worden dat het in Vos' beeldgedichten waarschijnlijk vaak om schilderijen van minder bekende schilders uit Frankrijk en Italië ging. ${ }^{22}$ De beeldgedichten zullen niet gericht geweest zijn op het prijzen van die schilders. In de gedichten stonden dan ook, net als in de portretgedichten, niet zo zeer de schilderijen en hun vervaardigers centraal, maar vooral datgene wat op de afbeelding te zien was. Vos deed geen uitspraken over schildertechnieken, lichtval of kleurgebruik, en sloot daarmee aan bij de conventies van het genre. ${ }^{23}$

Dat ook voor deze beeldgedichten geconcludeerd moet worden dat de relatie met de Amsterdamse regenten een belangrijke reden was om ze te schrijven, blijkt uit het feit dat zeker de helft van de bezongen afbeeldingen in bezit was van regenten. Deze worden echter in de gedichten net zo goed als de schilders vaak niet genoemd, dus de beeldgedichten functioneerden niet, zoals de portretgedichten, als lofdichten. De vraag is nu hoe deze beeldgedichten wel gefunctioneerd hebben in de relatie met de eigenaars.

Voor enkele gedichten is die functie makkelijk te achterhalen. Dat geldt in de eerste plaats voor de bijschriften, korte beeldgedichtjes die puntig een afbeelding beschrijven en van een passende morele boodschap voorzien zijn. Dergelijke gedichten werden vaak opgenomen op of onder de afbeelding, maar dat geldt zelden voor Vos' bijschriften. Het gedichtje 'Op d'afbeelding van de Heerlijkheidt van Maarseveen' is inderdaad te lezen op een plattegrond van Maarsseveen, ${ }^{24}$ maar vaker schreef Vos bijschriften die afzonderlijk van de afbeeldingen gepubliceerd werden. Deze bijschriften verwezen echter zo duidelijk naar de afbeeldingen dat ze gefunctioneerd moeten hebben als 'reclame'. Dat geldt bijvoorbeeld voor de gedichten die hij schreef naar aanleiding van de decoratie van het nieuwe stadhuis, dat in 1655 betrokken werd. In het stadhuis waren bijschriften van Vondel te lezen onder de schilderijen, maar de burgemeesters zullen ook blij geweest zijn met de extra publieke aandacht die de gedichten van Vos genereerden. De aankleding van het nieuwe stadhuis, waar ze zoveel geld in hadden gestoken en waar zoveel symboliek in zat, kon hen waarschijnlijk niet genoeg bezongen worden.25

Een minder bekend voorbeeld zijn de bijschriften die Vos in 166I of 1662 schreef bij de plafondschilderingen in de huizen van de rijke Amsterdamse koopmannen Louis en Hendrik Trip. ${ }^{26}$ De broers betrokken in 1662 het speciaal voor hen gebouwde dubbelhuis aan de Kloveniersburgwal, het zogenaamde 'Trippenhuis'. De broers, rijk geworden in de wapenhandel, lieten het huis rijkelijk versieren, onder andere met allegorische plafondschilderingen. Vos bezong deze schilderingen in bijschriften die onder andere gepubliceerd werden in Fokkens stadsbeschrijving van $1662 .{ }^{27}$ Vos hielp met zijn bijschriften de faam van de gebroeders Trip in Amsterdam te verspreiden. ${ }^{28}$

De meeste beeldgedichten van Vos waren veel te lang om als bijschrift te functioneren. ${ }^{29}$ In gedichten naar aanleiding van historieschilderkunst stond hij vaak uitgebreid stil bij de op het schilderij verbeelde scène. Wat opvalt is dat vaak een morele lezing van het verbeelde gegeven wordt. De op historieschilderijen verbeelde geschiedenissen ontlokten aan de dichter allerlei uitspraken van didactisch-moralistische aard. Die konden over de 
meest uiteenlopende onderwerpen gaan, zoals politiek, religie, of iets specifieks als opvoeding. Wanneer de eigenaar van zo'n schilderij genoemd werd en het gedicht werd gepubliceerd, werd op deze manier publiekelijk onderstreept wat de (morele) waarde van diens kunstbezit was. De regenten werden geprezen voor hun bezit, en in sommige gevallen werkte de nadruk op de morele werking van de schilderkunst ook ter verdediging van het bezit van religieuze schilderijen die de calvinistische kunstkritiek eigenlijk niet konden doorstaan..$^{30}$

De meeste beeldgedichten van Vos bij historieschilderkunst zijn echter alleen overgeleverd in Alle de gedichten. Dat betekent dat hun publieke functie gering is geweest, of in ieder geval niet uitgebuit is. Ik vermoed dat deze gedichten een concrete sociale functie vervuld hebben in regentenhuishoudens. Het gaat om gedichten die door lezers enkel als beeldgedichten herkend konden worden omdat ze opgenomen waren in secties van het verzameld werk met weinig aan de verbeelding overlatende titels als 'Byschriften op schilderyen' of 'Byschriften op afbeeldingen'. Opvallend is de dominante topiek van de levendigheid: de gedichten bieden een dramatische vertolking van de afgebeelde episode, die de natuurgetrouwheid of levendigheid van het schilderij onderstreept.

Deze thematiek is verwant aan de belangrijkste motieven uit de kunsttheorie, die al sinds de klassieke oudheid een rol speelden in gedichten over schilderijen: de verhouding tussen schilderkunst en werkelijkheid en de verhouding tussen schilderkunst en literatuur. ${ }^{31}$ Enargeia, ook wel evidentia, raakt aan de kern van beide motieven. ${ }^{32}$ Enargeia - het aanschouwelijk maken - is een bekende term uit de klassieke retorica die veel zeventiende-eeuwse dichters in de praktijk brachten. Juist in ekphrastische genres, zoals beeldgedichten, speelde enargeia een belangrijke rol. ${ }^{33}$ Dat heeft alles te maken met de paragone tussen dichtkunst en schilderkunst, waarin mimesis - nabootsing - centraal stond. ${ }^{34}$ Het levendig beschrijven dat de enargeia behelst, diende om de poëzie in het kader van de paragone dezelfde mimetische 'kracht' te geven als de schilderkunst. Mimesis werd in de klassieke retorica van groot belang geacht voor de overtuigingskracht en het bespelen van de emoties. ${ }^{35}$ Enargeia werd in de schilderkunst, net als in de dichtkunst, nagestreefd ten behoeve van deze mimesis, al werd het in kunsttheoretische geschriften niet onder deze term behandeld. ${ }^{36}$ Zo was enargeia het verbindende element tussen de dichtkunst en de schilderkunst: als beide kunsten hetzelfde doel nastreefden (mimesis) met hetzelfde middel (enargeia), konden zij als 'zusterkunsten' door het leven gaan.

Het hoeft dus niet te verbazen dat motieven die de levendigheid van het schilderij onderstrepen onder invloed van de vroegzeventiende-eeuwse Italiaanse dichter Giambattista Marino (1569-1625) conventioneel werden in ekphrastische genres. Ze kwamen dan ook bij Vos' collegadichters voor, maar van alle Nederlandse dichters zijn ze bij Vos misschien wel het dominantst. ${ }^{37}$ In zijn beeldgedichten worden de levendigheid en natuurgetrouwheid van zowel schilderij als gedicht voortdurend impliciet benadrukt door het inzetten en tot het uiterste doorvoeren van enargeia en door andere middelen, zoals vragen en uitroepen die een concrete reactie op het verbeelde weergeven en het aanspreken of laten spreken van de figuren op het schilderij. Figuren uit de afbeelding kunnen in gesprek gaan met degenen die het schilderij bekijken; de beschouwers van het schilderij kunnen onpasselijk worden van datgene wat ze afgebeeld zien of er juist opgewonden van raken; en de verbeelde gebeurtenissen worden beschreven alsof ze in het hier en nu plaatsvinden. Vos speelde in zijn gedichten een spel door schilderij en werkelijkheid door elkaar te laten lopen.

Illustratief is het gedicht 'Adam en Eva, door d'Engel uit het Paradijs gedreeven, door S.D. geschildert', dat Vos schreef over een mij onbekend schilderij dat in het huis op Huydecopers buitenplaats Goudesteijn hing. ${ }^{38}$ Het gedicht werd alleen gepubliceerd in Alle de gedichten, als onderdeel van een serie beeldgedichten in Huydecopers bezit. In het gedicht reageert de beschouwer op de afgebeelde vlucht van Adam voor de engel die hem (en Eva, maar zij wordt in het gedicht niet genoemd) uit het Paradijs komt verdrijven na de zondeval: 
Wat schriklijk wonder komt mijn ziel door kunst aanranden?

Hier komt een engel, op 't misdrijf van Adam, af;

Zijn scherpe slagzwaardt brandt: maar zonder te verbranden.

In de eerste regel wordt naar het schilderij verwezen: de ziel van de beschouwer wordt geraakt door wat hij voor zich ziet gebeuren (het wordt niet expliciet gemaakt dat dit op een schilderij is) en wat hij benoemt als een 'schriklijk wonder'. Vervolgens wordt Adams vlucht beschreven alsof de beschouwer er naast staat. Door algemeen geldende uitspraken (sententies) wordt er in het middenstuk van het gedicht een moralistische interpretatie gegeven die iets meer afstand suggereert, maar in de afsluiting komt de verbeelde scène opeens weer heel dichtbij:

Wie dat met my de macht van 't hemelrijk wil tergen,

Vertrek van hier, het zwaardt is vaardigh om te slaan:

Ik vlucht voor uit, eer dat de vlam my komt verslinnen.

Het is onduidelijk of hier de beschouwer nog steeds aan het woord is, en zowel Adam als zijn medebeschouwers toespreekt, of dat Adam hier spreekt, maar het komt er in beide gevallen op neer dat degenen die naar het schilderij kijken met het gedicht in de hand, aangespoord worden te denken dat de engel die op het schilderij achter Adam aan zit, ook achter hen aan zit, en dat ze dus ook moeten vluchten. De verlevendiging van het beeld dient in dit gedicht de moralistische interpretatie die door de sententies onderstreept wordt: de beschouwers worden er door schilderij en gedicht op gewezen dat straffen van God onontkoombaar zijn en dat God, ondanks zijn straffen, geliefd moet worden.

In andere gedichten is de moralistische interpretatie minder dominant aanwezig, maar speelt de verlevendiging een des te grotere rol. Dat is bijvoorbeeld het geval in het gedicht 'Orestes moedermoordt, door N.G. geschildert', op een eveneens onbekend schilderij uit dezelfde collectie van Huydecoper $s r .{ }^{39}$ Het moet gaan om een schilderij waarop Orestes, de zoon van Agamemnon en Clytaemnestra, op het punt staat zijn moeder te doden om zijn vaders moord te wreken. Ik citeer het gedicht in zijn geheel:

Orest' hou standt; of kom uw moeders hooft niet naader;

Verwerp de moordtbijl: want zy krijgt $\mathrm{u}$ in 't gezicht.

Hoe! moeder? neen: het is de moordtster van mijn vaader.

Wie vaaders moordtwondt wreekt voldoet zijn kinderplicht.

De kinderplicht wordt zelf van 't goodendom verheeven.

Gy staat hier naar de doodt van die u't leeven gaf.

Eerst gaf zy't my: daar na zoo stondt zy my naa 't leeven.

Wie met de wil vermoordt verdient de volle straf.

Ik heb door zusters zorg het leeven noch behouwen.

Wie iemandts leeven bergt doet meer dan die hem teelt.

Het teelen komt, bywijl, door dartelheidt der vrouwen,

En teegens wil: maar dit is liefde zonder weeldt.

Wie 't kindt met wil vermoordt heeft moeders naam verlooren.

' $k$ Ontken ' $t$ niet: maar de zoon heeft nooit het recht gehadt,

Om haar, om vaadermoordt, door 't staal, in bloedt te smooren.

Vertoef. hy slaat. 't is helsch. hier vloeit een bloedig badt.

Zoo toont hy moeders aart van alle trouw verbastert.

Een moedermoorder wordt van Godt en mensch gelastert. 
De dichter gaat in dit gedicht de dialoog aan met de hoofdfiguur op het schilderij, alsof het om een werkelijk persoon gaat. In het begin van het gedicht wordt Orestes aangesproken en aangespoord zijn moeder niet te vermoorden $(\mathrm{I}-2)$. Orestes reageert verontwaardigd op deze aansporing: hij vindt dat je de moordenaar van zijn vader geen moeder meer kunt noemen (3-5): 'Hoe! moeder? neen:' (3), zo begint hij zijn weerwoord. De dichter stelt dat Orestes desondanks niet degene kan vermoorden, die hem het leven gaf (6). Orestes neemt het woord weer en legt uit dat zijn zus Electra, die hem gered heeft, ware liefde voor hem koesterde, terwijl zijn moeder hem wilde vermoorden (7-I3). De dichter erkent dat, maar stelt dat het desalniettemin niet mag, je moeder vermoorden (I4-I5). Daarmee is de dialoog ten einde. De dichter slaakt nog een laatste kreet in een poging Orestes tegen te houden ('Vertoef.,' 16) en kan daarna alleen nog maar toekijken. Hijgeeft een ooggetuigenverslag van het gebeurde: 'hy slaat.' $t$ is helsch.'( 16$)$, en concludeert ten behoeve van de toeschouwer dat Orestes zijn moeders aard blijkt te bezitten en als 'moedermoorder' door zowel God als mens belasterd zal worden (17-18).

Gedichten zoals deze lijken bij uitstek geschikt voor voordracht. Dat ze ook daadwerkelijk voorgedragen werden in regentenhuishoudens, is niet ondenkbaar. De sprekers worden niet geïntroduceerd en het is de lezer niet direct duidelijk wie wanneer aan het woord is. In sommige gedichten worden de beschouwers van het schilderij ook aan het woord gelaten of rechtstreeks aangesproken. Nog explicieter dan in het hierboven geciteerde gedicht over Adams vlucht gebeurt dat bijvoorbeeld in het gedicht 'Gevecht van de Horacien en Kuracien; door K.M. geschildert. Aan Mejuffer Leonora Huidekoopers van Maarseveen'. Leonora wordt rechtstreeks aangesproken en gewaarschuwd voor de strijd die op de afbeelding uitgevochten wordt: 'Wyk, Leonora, wyk, om doodsgevaar t'ontwijken.' ${ }^{\circ}$ Ook dit gedicht hoorde bij een schilderij dat in het huis op Huydecopers' buitenplaats Goudesteijn hing en je zou je goed voor kunnen stellen dat Vos, op bezoek in huize Huydecoper, een dergelijk theatraal gedicht daadwerkelijk als een soort toneelstukje opvoerde.

Gegevens over kunstbeleving en de rol van voordracht en oraliteit in het dagelijks leven versterken het vermoeden dat de levendige gedichten van Vos een theatrale functie hadden in regentenhuishoudens. In de klassieke oudheid werden ekphrastische genres bij uitstek geschikt geacht als 'progymnasmata': scholieren moesten hun voordrachtskunst demonstreren met ekphrasis. ${ }^{41}$ Bewijs voor een vergelijkbaar functioneren van beeldgedichten in de renaissance is niet overvloedig, maar een mooie casus biedt die van de Coryciana (I524). Deze Italiaanse dichtbundel ter ere van mecenas Johannes Goritz (?-1527) uit Rome bevat onder andere beeldgedichten die diens altaar in de kerk van S. Agostino sierden. Elk jaar op de dag van de heilige Anna organiseerde Goritz een feest waarbij vrienden uitgenodigd werden gedichten te schrijven en op te hangen bij de afbeeldingen. Die gedichten werden waarschijnlijk ook voorgedragen. ${ }^{42}$ Daarmee passen deze gedichten in een algemene vroegmoderne traditie van oraliteit en performativiteit die in bepaalde contexten, zoals die van de rederijkerij en de liedcultuur, aan de orde van de dag was. ${ }^{43} \mathrm{Het}$ voordragen van gedichten en toneelstukken in informele gezelschappen was bovendien niet ongewoon. ${ }^{44}$

Het zou tegelijkertijd kunnen dat de beeldgedichten van Vos de neerslag vormen van conversaties die bij het gezamenlijk beschouwen van een schilderij gevoerd werden. De dialoog in 'Orestes moedermoordt' geeft immers verschillende stemmen weer in een moreel dilemma. Karel Porteman heeft recent laten zien hoe iets vergelijkbaars aan de hand is in een ander gedicht van Vos, 'Lot met zijn dochters \&c. door V.J. geschildert.'45 In dit gedicht naar aanleiding van een schilderij met de populaire pikante thematiek van de Bijbelse Lot die verleid wordt door zijn dochters, zijn de sprekers lastiger te onderscheiden dan in 'Orestes moedermoordt'. Porteman noemt het gedicht 'verbrokkeld' en construeert hoe dat verbrokkelde een conversatie herbergt waarin verschillende sprekers uiteenlopende meningen verkondigen. Zowel verschillende beschouwers als figuren uit de afbeelding komen aan het woord en Porteman kan zich goed voorstellen dat het 
'voordrachtstuk' levendig gedeclameerd werd. ${ }^{46}$

De gedichten lijken zo te passen bij de vroegmoderne participerende kunstbeleving. Op basis van een analyse van werken van Pieter Breughel de Oudere (I525-1569) en hun plaats in huishoudens heeft Todd Richardson kort geleden beargumenteerd dat schilderijen in de zestiende eeuw inderdaad als 'conversatiestukken' gezien werden. Hij laat zien hoe beschouwers van schilderijen zoals die van Breughel in private omgeving met die schilderijen in gesprek gingen. De schilderijen functioneerden als aanleiding voor discussie en analyse, waarbij de deelnemers hun geleerdheid, spitsvondigheid en retorisch vernuft konden tonen. ${ }^{47}$

Het onderzoek van Richardson maakt deel uit van een recente tendens met veel aandacht voor de rol van de beschouwer en de interactie tussen kunstwerken en gebruikers. Waar Richardson zich baseert op de schilderijen, baseren andere onderzoekers zich hierbij op teksten, waaronder beeldgedichten. Voor Eric Jan Sluijter zijn gedichten en kunsttheoretische teksten bijvoorbeeld aanleiding geweest om te spreken van de 'virtual reality' van de schilderkunst. ${ }^{4}$ Norman Land heeft het over de 'ekphrastic response to art' in zestiende-eeuwse Italiaanse gedichten: kunst zou beschouwd worden als uitbeelding van de werkelijkheid en een actieve rol spelen in het leven van particuliere kunstbezitters. ${ }^{49}$

Juist ook de dominantie van enargeia in ekphrastische genres is dus een van de redenen geweest om uit te gaan van dergelijke ideeën over kunstbeschouwing en het kan bijna niet anders of deze actieve, participerende kunstbeleving moet ten grondslag hebben gelegen aan de uitgebreid uitgewerkte topiek van de levendigheid in de beeldgedichten van Vos naar aanleiding van historieschilderkunst in het bezit van Amsterdamse regenten. Hoewel theatrale elementen die de levendigheid van een schilderij benadrukten, zoals het aanspreken of laten spreken van de geschilderde figuren, het ekphrastische ooggetuigenverslag en vragen en uitroepen die een concrete reactie op het verbeelde weergeven, in veel van Vos' beeldgedichten voorkomen, valt het op dat het met name de ongepubliceerde gedichten voor Huydecoper en andere regenten zijn die zo stevig verankerd zijn in deze traditie..$^{\circ}$

\section{De Strydt}

Het lange gedicht Strydt tusschen de Doodt en Natuur, of Zeege der Schilderkunst gaat over een aanval op de mensheid door de allegorische figuur Dood. ${ }^{\mathrm{sI}}$ De mens vraagt Natuur om hulp, maar Natuur blijkt niet bij machte de aanval van de Dood definitief af te wenden. In totale wanhoop klopt Natuur dan bij de Schilderkunst aan. Met hulp van Schilderkunst lukt het wel de Dood te lijf te gaan. Het gedicht is dus een lofzang op de schilderkunst en meestal wordt aangenomen dat Vos het schreef naar aanleiding van het jaarfeest van het Amsterdamse St. Lucasgilde, waarin de schilders verenigd waren, op 21 oktober 1654.52

Met de opdracht aan Cornelis de Graeff richtte Vos zich echter tot een burgemeester die niet actief bij de oprichting van de Broederschap betrokken was, in tegenstelling tot collegaburgemeester Joan Huydecoper sr. Ook de gedichten die opgenomen zijn achter de Strydt, hebben eerder te maken met de relatie tussen Vos en de stadsregenten, dan met de relatie tussen Vos en de schilders. ${ }^{53}$ Wie het gedicht nauwkeurig leest, ziet dat het inderdaad niet in de eerste plaats draait om lof voor de schilderkunst. ${ }^{54} \mathrm{Er}$ is ook lof voor de dichtkunst en bovendien is de lof op beide kunsten onderdeel van de patronagegedachte die het werkelijke onderwerp van het gedicht is.

Als de figuur Schilderkunst in het gedicht geïntroduceerd wordt, samen met de Dichtkunst, blijkt welke taak de beide kunsten toegedicht wordt:

Deez' twee zijn by de Grooten groot geacht.

De kunsten gaan tot in de Konings zaalen. (402-403) 
Dichtkunst en schilderkunst worden hooggeacht door belangrijke mensen en bedienen zelfs koningen. Dat deze belangrijke mensen meer concreet gezien moeten worden als de Amsterdamse regenten, blijkt uit de rest van het gedicht. De lange lofzang op de Schilderkunst is vooral ook een lofzang op de stad Amsterdam. Met terugwerkende kracht wordt de voorspelling gedaan dat er een stad zal ontstaan, Amsterdam, die het 'hooft der watersteên' (452) zal zijn en waar mannen door 'wijze raaden, / Hun landt behoeden voor het woest Geweldt' (473-474). Deze lof op Amsterdam betreft dus ook zijn politieke en commerciële betekenis, maar de meeste aandacht gaat uiteraard uit naar de kunsten. Het zal in Amsterdam niet alleen 'grimmelen van schilders', maar ook van 'Poëeten' (45I), en 'Apollo zal hier met Apelles paaren' (459).

De aandacht voor de dicht- en schilderkunst in de voorspelling maakt deel uit van een web van impliciete verwijzingen naar patronage. $\mathrm{Al}$ in de hierboven geciteerde sententies over de waardering van de schilderkunst en de dichtkunst door de 'Groten' was sprake van patronagethematiek, maar in de voorspelling waarmee het gedicht afsluit is deze thematiek nog veel sterker aanwezig. De lof voor Amsterdam stoelt grotendeels op haar bescherming van de kunsten. Andersom worden faam en voortbestaan van de stad rechtstreeks aan deze kunsten gekoppeld: 'Die Stadt zal zich zoo ver, door haare verven / Doen roemen, als haar scheepen zee beslaan' (469-470). De dichter sluit de Strydt af met een peroratio waarin de aardse onsterfelijkheid van de mensheid centraal staat - maar dan met name de onsterfelijkheid van de mannen die het land besturen. Amsterdam wordt in de Strydt niet alleen opgevoerd als de beschermer van de kunst, de kunst wordt ook opgevoerd als de beschermer van Amsterdam.

De schilders die aan het eind van het gedicht door Natuur genoemd worden ter illustratie van de voorspelling (46I-466), moeten waarschijnlijk ook in verband gebracht worden met deze patronagethematiek. Zij zijn wel geïnterpreteerd als de schilders die door Vos en zijn tijdgenoten als de belangrijksten beschouwd werden, terwijl Weber veronderstelt dat Vos de schilders opgesomd zal hebben die bij de viering in oktober 1654 aanwezig waren.ss Beide hypotheses kunnen correct zijn en er zijn er meer te formuleren. Het zou bijvoorbeeld ook kunnen dat het om (bevriende?) schilders ging die Vos op deze manier onder de aandacht van de regenten wilde brengen. ${ }^{56}$ Een gemene deler is in ieder geval dat de meeste schilders in Vos' rijtje in contact stonden of zouden komen met Amsterdamse stadsregenten. De genoemde schilders zijn, in volgorde van opkomst: Rembrandt (1606-1669), Flinck, Emmanuel de Witte (1618-1692), Nicolaas van Helt Stockade (1614-1669), Van der Helst, Salomon Koninck (1609-1656) en Philips Koninck (1619-1688), Artus Quellinus (1609-1668), Jacob van Loo (1614-1670), Rombout Verhulst (1624-1698), Karel van Savoijen (1621-1665), Gerard Pietersz. van Zijl (ca. 1609-1665), Jan Gerritsz. van Bronckhorst (1603-1661), Willem Kalf (1619-1693), Ferdinand Bol (1616-1680), Barent Graat (1628-1709) en 'Blom', met wie Jan Blom (1622-1685) of Matheus Bloem (werkzaam ca. 1637-1666) bedoeld kan zijn.77

Veel van de genoemde schilders betekenden iets voor de stadsregenten omdat ze bijvoorbeeld portretten of andere schilderijen vervaardigden voor regentenhuishoudens of stedelijke gebouwen. ${ }^{8} \mathrm{Ze}$ ondersteunen dus de patronagegedachte in het gedicht. Vos' Strydt zelf kan op deze manier ook geïnterpreteerd worden als een ondersteuning van de bloei van Amsterdam. Niet alleen door de lof voor Amsterdam aan het eind van het gedicht, maar ook doordat elders in het gedicht talloze sententies in verband te brengen zijn met de regenten. Dat geldt bijvoorbeeld voor de tweeregelige sententie 'Wie zich in dienst begeeft van groote rijken, / Moet wakker zijn tot heil van't algemeen' (19-20), of voor 'Men krijgt geen zeege dan door dapperheeden' (77). Behalve met de sententies sloot Vos ook met de evidentia in het gedicht aan bij het discours dat de regenten aansprak. De dramatische, visuele stijl die zoveel gedichten van Vos domineert, kenmerkt ook de Strydt. En omdat het in dit gedicht draait om de kracht van de schilderkunst (voor de stad), is dat van extra belang. Vos laat met de Strydt zien dat hij, net als de schilders die hij in zijn gedicht opsomt, in staat is de strijd met de Dood aan te gaan, al maakt hij dat niet expliciet. 
Vos en de schilders

Uit bovenstaande blijkt dat niet alleen Vos' portretgedichten en beeldgedichten, maar ook een lofdicht dat op het eerste gezicht volledig in het teken staat van schilders en de schilderkunst, een belangrijke rol speelden in Vos' relatie met de stadsregenten, en minder relevant waren voor het contact dat Vos met schilders onderhield. Datzelfde geldt, opvallend genoeg, voor de meeste gedichten die Vos aan schilders adresseerde.

Voor iemand die verondersteld wordt intensieve contacten te onderhouden met schilders, schreef Vos maar weinig gedichten waarin hij zich tot individuele schilders richtte. Het gaat om zo'n tien gedichten, waarvan de meeste een incidenteel karakter hebben. Zo schreef Vos korte gedichten naar aanleiding van zijn eigen portretten door Jan Lievens (1607-1674) en Karel Du Jardin (1622-1678) (afb. 3-4).99 Deze gedichten zullen als bedankje en misschien zelfs ruilmiddel gefunctioneerd hebben: de schilders bezorgden Vos roem door hem te portretteren, hij hen door daarover te dichten. In tegenstelling tot Vos' andere portretgedichten propageren de gedichtjes op Vos' eigen portretten door Lievens en Du Jardin juist wél de kracht van de schilderkunst om onsterfelijk te maken. Ze stellen de schilderkunst daarin zelfs boven de dichtkunst. Tegelijkertijd dienden ze natuurlijk ook rechtstreeks Vos' zelfrepresentatie. In de gedichten stelt hij zich weliswaar conventioneel bescheiden op, hij vergeet niet melding te maken van zijn toneel, 'staatcywagens' en 'zeegeboogen'.

In twee gedichten over portretten van regentenvrouwen worden de schilders aangesproken. Het gaat om het gedicht bij het portret van Johanna Six (1628-1689), de echtgenote van koopman-regent Pieter Six, door Jan Lievens ( $A d g$ I, 182-183) en het gedicht bij het portret van Constantia Reynst, waarschijnlijk de Constantia (I638-1694) die later de schoondochter zou worden van Gerard Schaep (1599-1654), door Bartholomeus van der Helst ( $A d g \mathrm{I}, 798) .{ }^{60}$ In beide gevallen is al in de titel duidelijk dat de dichter zich in deze gedichten tot de schilder richt: de titel van het gedicht over Joanna Six eindigt met 'Aan Ian Lievensen' - zonder dat dus expliciet gemaakt wordt dat Lievens ook de schilder van het portret is - de titel van het gedicht aan Van der Helst luidt: 'Op d'afbeelding van Konstancy Reinst, Door vander Helst geschildert: aan den zelfde.' Vervolgens worden de moeilijkheden van het afbeelden van deze mooie vrouwen aan de orde gesteld en worden de schilders aangespoord de beste materialen te gebruiken. In het gedicht voor Van der Helst gebeurt dat in één regel - 'Een geestig ommetrek vereist een wis penseel' - in het gedicht voor Lievens wordt vrijwel het hele gedicht van 36 regels er voor uitgetrokken. Vos speelt in dit gedicht met topen uit liefdes- en lofdichten: de dichter spoort de schilder onder andere aan om als verf 'goodelyk ambrooz" (ro) te gebruiken en voor het 'blaakendt vuur' (25) van haar gezicht 'twee helle zonnestraalen' (27).

Of Lievens er wel of niet in is geslaagd of kan slagen om Joanna op deze manier te schilderen, blijft ongewis. Het gedicht is weliswaar aan Lievens gericht, het draait toch vooral om Joanna Six. De schilder komt in het hele gedicht niet voor. Dat is anders in het gedicht aan Van der Helst. Hier wordt de schilder wel degelijk geprezen als de 'Duitsche Apelles' (I) die erin slaagt Constancia Reynst af te beelden alsof ze leeft. Maar ook hier ontbreekt de lof voor Reynst uiteraard niet. De gedichten voor Lievens en Van der Helst hebben dus een dubbele functie. Hoewel de schilders aangesproken en geprezen worden in de gedichten, is de lof voor de geportretteerden ook een belangriike pijler in de gedichten, en in dat voor Johanna Six zelfs de belangrijkste. Het is dus mogelijk dat Vos de gedichten niet werkelijk voor Van der Helst of Lievens schreef, maar voor de families Reynst en Six. Het aanspreken van de schilder functioneert dan gewoon als een speels uitgangspunt om de schoonheid van de vrouwen te bezingen. Het is echter ook niet uit te sluiten dat de schilders deze gedichten van Vos cadeau gekregen hebben, maar misschien schreef Vos ze in dat geval wel namens de opdrachtgevers, bij wijze van dank.

De tot nu toe genoemde gedichten getuigen dus niet noodzakelijk van intensief contact tussen Vos en de schilders, hoewel Lievens met zijn twee gedichten een opvallende plaats lijkt in te nemen. Ook aan beeldhouwer Artus Quellinus de Oude (1609-1668) schrijft 
Jan Lievens, Portret van Jan Vos, houtskooltekening, $32,5 \times 25,6 \mathrm{~cm}$ Frankfurt, Städel Museum, inv.nr. 28361

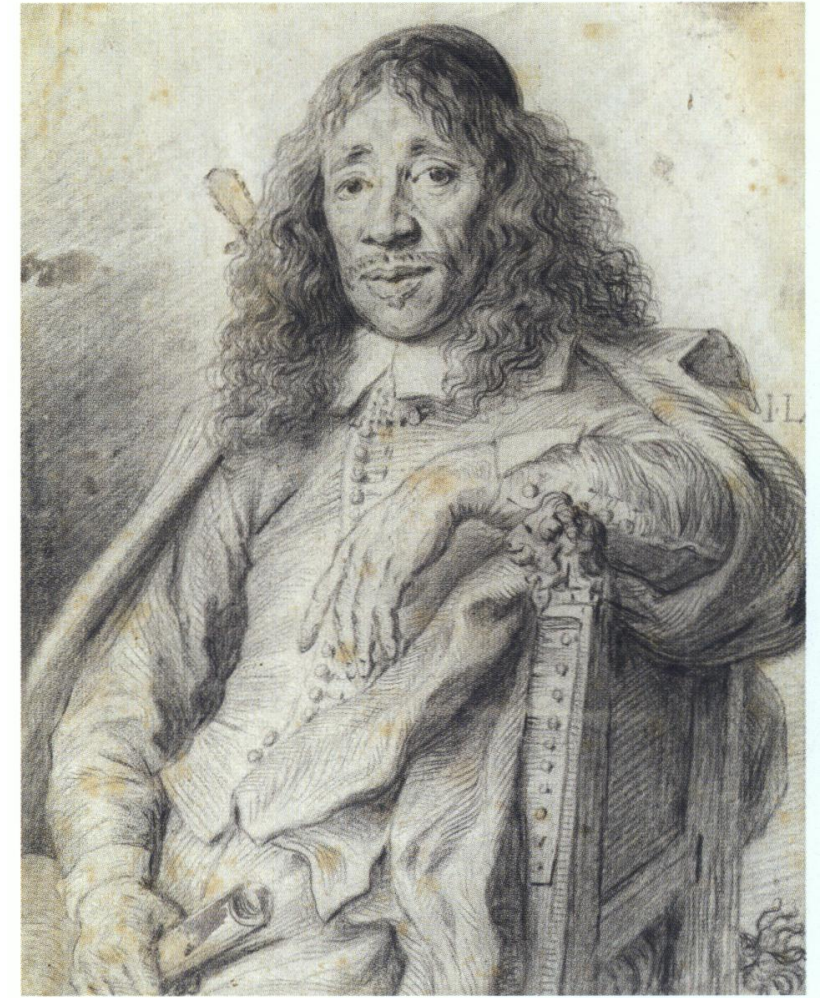

Vos twee gedichten, en zowel Lievens als Quellinus worden regelmatiggenoemd in titels van portret- en beeldgedichten naar aanleiding van door hun vervaardigde schilderijen en beelden. ${ }^{6}$ De schilder die de meeste aandacht krijgt in Vos' gedichten, is echter Govert Flinck. Voor hem schreef Vos vijf gedichten, en Flincks naam komt voor in de titels van ten minste vijf beeld- en portretgedichten.

Vos schreef een gedicht bij Flincks zelfportret, een gedicht naar aanleiding van diens beeldenverzameling en een grafschrift. ${ }^{62}$ Daarnaast zijn er nog twee humoristische beeldgedichten waarin Flincks werkwijze centraal staat: het voor zichzelf sprekende 'Aan G. Flink, toen hij een geschilderde Venus in Maria Magdaleena veranderde, \&c.' en 'Christus, voor Joris de Wyze, door Govert Flink, naar een Joodt geschildert', over de voor christenen paradoxale situatie dat Flinck voor het schilderen van een Christusfiguur een Joodse man gebruikte als model. ${ }^{63}$ Deze gedichten zijn uitzonderingen onder Vos' beeldgedichten omdat ze niet ingaan op wat afgebeeld is, maar op hoe de afbeelding tot stand gekomen is. Ze getuigen er bovendien van dat Vos wist hoe Flinck werkte. Dat hij in Flincks atelier kwam, blijkt ook uit het gedicht 'Op de Beeldekas van G. Flink', waarin de beeldenverzameling in Flincks atelier bezongen werd. ${ }^{64}$

Dit gedicht is, net als het portretgedicht en het grafschrift, redelijk conventioneel, maar wel zeer lovend. Flinck wordt in het portretgedicht, het grafschift en het gedicht op zijn 'beeldekas' gepresenteerd als de schilder met de hoogste positie op de 'dubbele Parnas', hij wordt vergeleken met grote dichters (Vergilius) en steeds wordt de eeuwigheidswaarde van zijn kunst onderstreept. Flinck was als geen ander in staat de Dood te tarten, zo moeten we concluderen uit Vos' gedichten over Flinck.

Dat Vos met zijn contact met Flinck pronkte, hoeft niet te verbazen. Dat juist het contact met Flinck, Lievens en Quellinus een plaats krijgt in Vos' oeuvre, en dat Flinck zo uitgebreid geprezen wordt, moet alles te maken hebben met de positie van de schilders en de beeldhouwer in regentenkringen. Alledrie hadden ze net als Vos de Amsterdamse stadsregenten als belangrijkste patronen en ze hadden in deze kringen een zeer goede positie, waarbij Flinck de kroon spande. ${ }^{65} \mathrm{Het}$ is dan ook heel goed mogelijk dat het contact tussen Vos en Flinck tot stand gekomen is toen Vos en Flinck samenwerkten voor het schuttersstuk van Huydecoper sr. Het zou zelfs kunnen dat Vos' portretgedichtje 


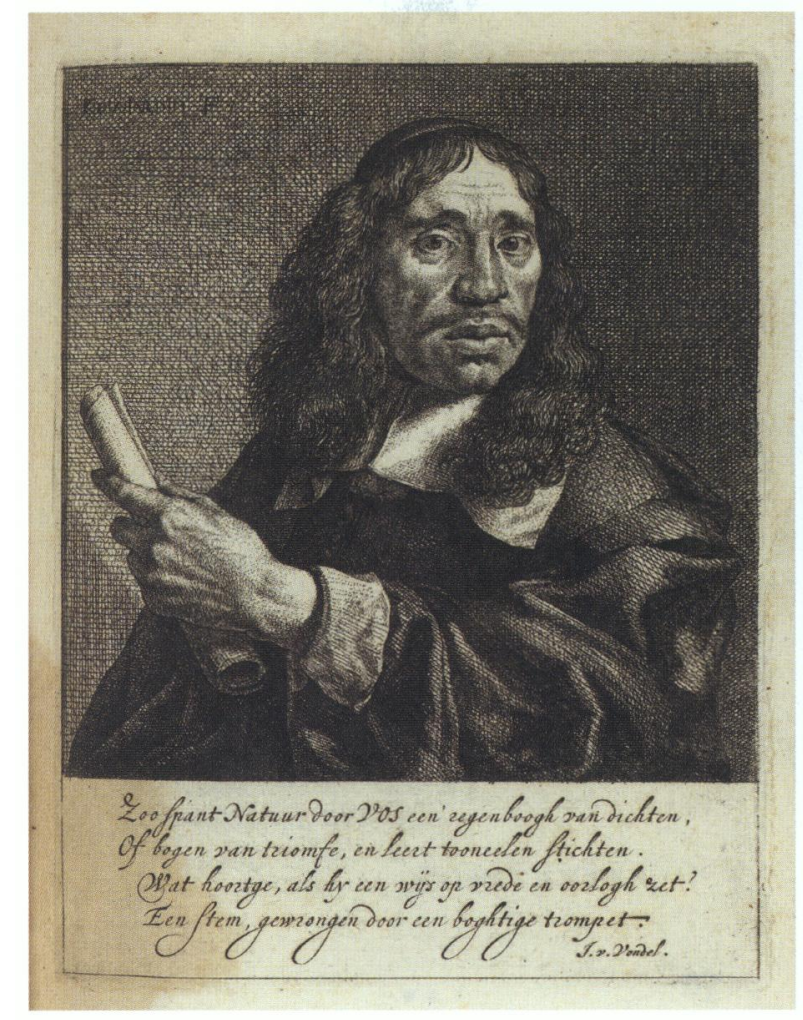

voor Flinck uit die samenwerking is voortgekomen: Flinck gaf ook zichzelf een plaats op dat schuttersstuk, terwijl het enige echte zelfportret van Flinck dat overgeleverd is, al in 1639 gemaakt werd.${ }^{66}$ Ook het grafschrift over Flinck kwam tot stand op een moment dat schilder en dichter samenwerkten voor de regenten. Flinck overleed op het moment dat hij net de megaopdracht voor het nieuwe stadhuis had binnengehaald, het gebouw waaraan Vos als glazenmaker meewerkte en dat hij later in een lang inwijdingsgedicht de hemel in zou prijzen. ${ }^{67}$ Vos' betrokkenheid bij het nieuwe gebouw dat de glorie van Amsterdam moest onderstrepen, toonde hij ook door een gedichtje te schrijven naar aanleiding van het overlijden van de belangrijkste schilder die bij het project betrokken was.

De laatste schilder die niet ongenoemd mag blijven, is de Deense hofschilder Karel van Mander III (ca. 1610-1670). Het is onduidelijk of Vos Van Mander ooit ontmoet heeft, maar ook Van Mander wordt vijf keer genoemd in titels van portret- en beeldgedichten bij schilderijen van zijn hand, en bovendien richtte Vos zich tot hem in een brief. ${ }^{68}$ De brief werd gepubliceerd in Hollantsche Parnas (1660), een bloemlezing die samengesteld werd door twee goede bekenden van Vos, Jacob Westerbaen en Tobias van Domselaer, en houdt nadrukkelijk verband met Vos' stadsdichterschap. In de brief stuurde Vos de beschrijving van een van de vertoningen die hij in I 654 maakte ter gelegenheid van de vrede met Engeland, 'ter liefde van de kunsten, die wy beide oeffenen'. De beschrijving voorspelt een verbond tussen de Republiek en Denemarken, dat er ondertussen gekomen was en geleid had tot een doorslaggevende interventie van de Republiek in de Noordse oorlog tussen Denemarken en Zweden in 1658. Deze interventie betekende voor Denemarken de redding van de ondergang, en voor Amsterdam het veilig stellen van de vrije doorgang door de Sont, de belangrijke handelsroute naar de Oostzee. In de Republiek bestond veel onenigheid over de rol die de Nederlanders in de Noordse oorlog moesten spelen en Vos droeg met zijn brief aan Van Mander de Amsterdamse visie uit, net als met de vele portretgedichten die hij schreef naar aanleiding van door Van Mander geschilderde portretten van de Deense vorsten en andere hoflieden. 


\section{Besluit}

Vos kende beslist veel schilders en met verschillende van hen moet hij veel contact gehad hebben. Het valt echter op dat deze contacten in Vos' oeuvre slechts een kleine rol spelen. Van alle uitingen in Vos' gedichten die in verband gebracht kunnen worden met schilders en de schilderkunst, lijken alleen enkele gedichten voor Flinck een rol gespeeld te hebben in het onderhouden van de relatie met de schilder zelf, en dat is vermoedelijk niet toevallig de schilder die op dat moment het hoogst in aanzien stond bij zijn patronen. Vos' opvallende voorliefde voor schilders, de schilderkunst en het beeldende moet dus eerst en vooral in verband gebracht worden met zijn patronagerelatie met de Amsterdamse stadsregenten.

\section{NOTEN}

I Zie bijvoorbeeld G. Weber, Der Lobtopos des 'lebenden' Bildes: Jan Vos und sein Zeege der Schilderkunst von ${ }_{1} 6_{54}$, Hildesheim, Zürich en New York 1991, pp. 17-21; A. Blankert, Ferdinand Bol (I6I6I680): Rembrandt'spupil, Doornspijk 1982, pp. 21, 74; W.J.C Buitendijk, Jan Vos' Toneelwerken, Assen, Amsterdam 1975, pp. 8-9; M.A. Schenkeveld-van der Dussen 'Ut pictura poesis? De paragone tussen dicht- en schilderkunst bij Jan Vos en Jan Six van Chandelier, Nederlandse letterkunde 6 (2001) 2 , pp. 102-103.

2 Buitendijk 1975 (noot I), pp. 19-2I Weber 1991 (noot I), m.n. hoofdstuk 4 .

3 G. Schwartz, 'Apelles, Apollo en The Third Man. Schilderkunst, letterkunde en politiek rond 1650, De zeventiende eeuw II (1995) I, pp. I22-132.

4 Jan Vos, Alle de gedichten, $2 \mathrm{dln}$., Amsterdam: Jacob Lescaille, 1662 en 1671. Aan de twee delen wordt in het vervolg gerefereerd met $A d g$ I en $\operatorname{Adg}$ II.

5 Deze suggestie heb ik eerder gedaan in N. Geerdink, 'De man van het beeld aan het woord. Jan Vos' Zeege der schilderkunst (1654)',

Nieuw Letterkundig Magazijn 28 (2010) 2, pp. 45-50.

6 Vgl. N. Geerdink, Dichters en verdiensten: de sociale verankering van het dichterschap van Jan Vos (1610-1667), Hilversum 2012 en N. Geerdink, 'Stadsdichterschap in de zeventiende eeuw. Jan Vos (16101667) en Amsterdam', Spiegel der Letteren 52 (2011) 4, pp. 443-460.

7 Deze paragraaf is deels gebaseerd op Geerdink 2012 (noot 6), pp. 50-54, 168-172, 206-207.

8 Vgl. A. Jensen Adams, Public faces and private identities in seventeenthcentury Holland: Portraiture and the production of community, Cambridge 2009 .

9 Over portretdichten als lofdichten ook I.M. Veldman, Crispijn De Passe and his progeny (1564-1670): A century of print production, Rotterdam 200I, p. 57. Dat portretgedichten soms niet eens naar aanleiding van een portret geschreven werden, blijkt uit: I. Broekman en J. Bloemendal, 'De Pastorum Hagiensium Icones van Constantijn Huygens (1596-1687): Een serie gedichten op Haagse predikanten' Tijdschrift voor Nederlandse Taalen Letterkunde 124 (2008), pp. 282-303.

10 Vgl. hierover bijvoorbeeld J.A. Emmens, "Ay Rembrandt, maal Cornelis stem", Verzameld werk, $\mathrm{dl}$. 3, Amsterdam 1981, pp. 61-97.

II $\operatorname{Adg}$ I (noot 4),pp. 194-195, ook opgenomen in J. Vos, Strydt tus schen de Doodt en Natuur, of Zeege der Schilderkunst, Amsterdam: Jacob Lescaille, 1654 ; Klioos Kraam, vol verscheiden gedichten: d'eerste opening, Leeuwarden: Henrik Rintjus, 1656; J. Vos, Dichtkunst van Jan Vos, Amsterdam: J. van Duisberg, 1658 .

$12 \operatorname{Adg} \mathrm{I}$ (noot 4), p. 784

13 S.A.C. Dudok van Heel, Van Amsterdamse burgers tot Europese aristocraten, dl. 3, Den Haag (te verschijnen), hoofdstuk I.

14 J. Vos, Vergrooting van Amsterdam, Amsterdam: Jacob Lescaille, 1662. Ook in $A d g$ I (noot 4), pp. 809838. Zie Geerdink 2012 (noot 6), pp. 43, 108-109, III-II2, 117, 143146,165 .

Is De gedichtjes bij de regentenportretten staan ook in $A d g$ I (noot 4), p. 160 (Schaep); p. 171 (Witsen); p. ${ }_{173}$ (Vlaming van Outshoorn); $p$. 195 (De Graeff); p. 202 (Van de Pol); p. 797 (Hooft).
16 Over de publieke plaats en functie van schuttersstukken: Jensen Adams 2009 (noot 8), pp. 211-258; A. Jensen Adams, 'Civic Guard Portraits: Private Interests and the Public Sphere', Nederlands Kunsthistorisch Jaarboek 46 (1995), pp. 169-197; P. Knevel, Burgers in het geweer: de schutterijen in Holland, I550-I70o, Hilversum 1994, pp. 311-322.

17 Adg I (noot 4), pp. 540-54I. Zi over het schuttersstuk van Flinck: N. Middelkoop (red.), cat. tent. Kopstukken: Amsterdammers geportretteerd, Amsterdam (Amsterdams Historisch Museum) 2002, pp. 204-205. Over de patronagerelatie tussen Vos en Huydecoper: Geerdink 2012 (noot 6), hoofdstuk 3.

$18 \operatorname{Adg}$ I (noot 4), p. 543, het gedicht is hier twee regels langer. Het schuttersstuk van Bartholomeus van der Helst bevindt zich, net als dat van Flinck, in het Rijksmuseum (inv.nr. SK-C-2).

19 Hiermee sluiten de gedichten in sommige gevallen direct aan bij de portretten: van pendantenportretten is bekend dat de vrouw vaak in een passievere houding afgebeeld werd dan de man, vgl. Middelkoop 2002 (noot 17), p. 14.

$20 \operatorname{Adg}$ I (noot 4), p. 193, regel 19-24

2I Deze paragraaf is deels gebaseerd op Geerdink 2012 (noot 6), pp. 87-93, III-117, I56-161, I86-194.

22 Ik ben tot deze conclusie gekomen in samenwerking met Marten Jan Bok en op basis van onderzoek in zijn database Ecartico: http:// burckhardt.ic.uva.nl/ecartico/ database.html.

23 Vgl. K. Porteman, 'Zeventiendeeeuwse schilderijenpoëzie als gezelschapskunst. Jan Vos over Lot en zijn dochters', Jaarboek $D e$ Fonteine 2006-2007 (2007), 
pp. 3-19, spec. p. 8. Alleen Vondel had in zijn beeldgedichten vaak wel aandacht voor de manier waarop schilders een bepaald onderwerp verbeeld hadden, vgl. H. Luijten, 'Book Review of: Gregor J.M.

Weber, Der Lobtopos des 'lebenden' Bildes: Jan Vos und sein 'Zeege der Schilderkunst' von 1654', Simiolus 22 (1993-1994), pp. 326-331, spec. p. 329 .

$24 \operatorname{Adg} \mathrm{I}($ noot 4), p. 547. Zie Geerdink 2012 (noot 6), pp. 80-81.

25 Hierover: Geerdink 2012 (noot 6), pp. $135,158,187-188$

26 'Op de Zinnebeelden in 't huis van den E. Heer Louys Trip, Door Niklaas Heldt Stockade, aan 't verwelfsel van de Zaal, geschildert.', Adg I (noot 4), pp. 772-774 en 'Op de Zinnebeelden in ' $t$ huis van den E. Heer Hendrik Trip, Door Niklaas Heldt Stokade, aan ' verwelfsel van de Zaal geschildert.', AdgI (noot 4), pp. 775-777.

27 M. Fokkens, Beschrijuinge der wijdt-vermaarde Koop-stadt Amstelredam, Amsterdam Abraham en Jan de Wees, 1662.

28 Snoep veronderstelt dat hij dat in opdracht deed, vgl. D.P. Snoep, 'Het Trippenhuis, zijn decoraties en inrichting', R. Meischke en H.E. Reeser (red.), Het Trippenhuis te Amsterdam, Amsterdam 1983, pp. I87-211, spec. p. 190; ik denk dat het ook goed mogelijk is dat Vos in ruil' voor zijn gedichten als glazenmaker betrokken werd bij de bouw. Over de verwevenheid van Vos' dichterschap en glazenmakerschap: N. Geerdink, 'Een glazenmaker op de Parnas: twee carrières van Jan Vos (1610-1667)', De zeventiende eeuw 27 (2011) 2, pp. 180-193, en Geerdink 2012 (noot 6), hoofdstuk

29 Een enkele keer is ook voor die gedichten wel een concrete functie aan te wijzen, zoals voor een gedicht dat Vos schreef naar aanleiding van een houten sculptuur van de Heilig Grafkerk in Jeruzalem: 'd'Afbeelding van Christus graf, door den Eed. Gestr. Heer Joan Huidekooper, Ridder, Heer van Maarseveen, Burgermeester \&c. aan my vereert \&c.' (Adg I (noot 4) pp. 558-559). Vos heeft het beeldje blijkens de titel van het gedicht van Huydecoper sr. cadeau gekregen, en hoewel er geen handschrift overgeleverd is, is het aannemelijk dat hij het bij wijze van dank voor

Huydecoper geschreven heeft: zie Geerdink 2012 (noot 6), pp. 87-88.

30 Zie Geerdink 2012 (noot 6), pp. 158-160.

31 K. Porteman, 'Geschreven met de linkerhand? Letteren tegenover schilderkunst in de Gouden Eeuw', M. Spies (red.), Historische letterkunde: facetten van vakbeoefening, Groningen 1984, pp. 93-113, spec. pp. 105-106.

32 Quintilianus gebruikte de term enargeia, waar Cicero de term evidentia gebruikte.

33 Zie voor de dominantie van enar geia in ekphrastische genres bijvoorbeeld N.E. Land, 'Titian's Martyrdom of St. Peter Martyr and the 'Limitations' of Ekphrastic Art Criticism', Art History 13 (1990) 3, pp. 293-317.

34 V. von Rosen, 'Die Enargeia des Gemäldes: zu einem vergessenen Inhalt des Ut-Pictura-Poesis und seiner Relevanz für das Cinquecenteske Bildkonzept', Marburger Jabrbuch für Kunstwissenschaft 27 (2000), pp. I7I-208.

35 Zie bijvoorbeeld C. van Eck, Classical rhetoric and the visual arts in early modern Europe, Cambridge 2007 , p. 33 en J. Konst, 'Een levende schoon-verwighe schilderije: de tragedie als historiestuk', in: A.C.G. Fleurkens et al. (red.), Dans der muzen: de relatie tussen de kunsten gethematiseerd, Hilversum 1995, pp. I03-115.

36 Over klassieke retorica en schilderkunst zie Van Eck 2007 (noot 35).

37 Zie Porteman 2009 (noot 23), p. 9. Over de invloed van Marino zie ook M. Albrecht-Bott, Die bildende Kunst in der Italienischen Lyrik der Renaissance und des Barock: Studie zur Beschreibung von Portraits und anderen Bildwerken unter besonderer Berücksichtigung von G.B. Marinos Galleria, Wiesbaden 1976; en Land 1990 (noot 33).

$38 \operatorname{Adg}$ I (noot 4), p. 545.

$39 \operatorname{Adg}$ I (noot 4), p. 548.

$40 A d g$ I (noot 4), pp. $547-548$. Het gaat om een schilderij waarop de strijd tussen de drie broers Horatius (namens Rome) tegen de drie broers Curiatius (namens Alba Longa) vochten, wellicht van Karel van Mander.

41 H. Luijten, 'Wat schriklijk wonder komt mijn ziel door kunst aanran den?' De 'Byschriften op schilderyen' van Jan Vos, doctoraalscriptie Universiteit Utrecht 1987, p. 7.

42 Zie hierover bijvoorbeeld J.H. Gaisser, 'The rise and fall of Goritz's feasts', Renaissance 2uarterly 48 (1995) I, pp. 4I-57 en J. IJsewijn, 'Poetry in a Roman garden: the Coryciana', in: P. Godman \& O. Murray (eds.), Latin poetry and the classical tradition: essays in
Medieval and Renaissance literature, Oxford 1990, pp. 21I-23I.

43 Vgl. over oraliteit en performativiteit bij rederijkers bijvoorbeeld A. van Dixhoorn, 'Chambers of rhetoric: performative culture and literary sociability in the early modern Northern Netherlands', in: A. van Dixhoorn \& S. Speakman Sutch (eds.), The reach of the Republic of Letters: literary and learned societies in late Medieval and early modern Europe, Leiden 2008, pp. I19-157. Zie over liedcultuur: N. Veldhorst, Zingend door bet leven. Het Nederlandse liedboek in de Gouden Eeuw, Amsterdam 2009. De orale liedtraditie lijkt overigens verwantschap te vertonen met beeldgedichten zoals die van Vos in haar 'spelkarakter': de conversatietoon die veel beeldgedichten van Vos kenmerkt, kwam ook in liederen voor. Zie Veldhorst 2009, pp. 97, 102.

44 J. Blaak, Geletterde levens: dagelijks lezen en schrijuen in de vroegmoderne tijd, Hilversum 2004 o.a. pp. 70, 93, 154-155, 295.

$45 \operatorname{Adg}$ I (noot 4), p. 559 . Hierover: Porteman 2009 (noot 23).

46 Porteman 2009 (noot 23), pp. 13-14.

47 T.M. Richardson, Pieter Breugel the Elder: art discourse in the sixteenthcentury Netherlands, Farnham en Burlington 2011, m.n. hoofdstuk 2. Zie voor de schilderkunst als gespreksonderwerp ook: Blaak 2004 (noot 44), pp. 52-55.

48 E.J. Sluijter, Rembrandt and the female nude, Amsterdam 2006 pp. IsI-Is3.

49 Vgl. N.E. Land, The viewer as poet: the renaissance response to art, University Park (PA) 1994 en Land 1990 (noot 33).

50 Vgl. ook de gedichtenreeks voor Witsen: Adg I (noot 4), pp. 54I543.

5I Adg I (noot 4), pp. 127-I4I. Het gedicht werd ook afzonderlijk gepubliceerd als Vos 1654 (noot II), en opgenomen in Klioos Kraam (noot II) en in Vos 1658 (noot II).

52 H. Postma \& M. Blok, 'Duidelijkheid over de Amsterdamse St. Lukasfeesten in I653 en 1654,' Oud Holland ros (1991) I, pp. 32-38, spec. p. 32.

53 Zie over deze gedichten Geerdink 2010 (noot s).

$54 \mathrm{Zie}$ voor een uitgebreide analyse van het gedicht Geerdink 2010 (noot 5), en Geerdink 2012 (noot 6), pp. 73-77. 
56 Dit is een suggestie van Eric Jan Sluijter.

57 Weber 1991 (noot I), pp. 33-45 geeft van alle schilders aan hoe ze in verband gebracht kunnen worden met Amsterdam en de Amsterdamse regenten. Willem Kalf is de enige voor wie dit lastig is, maar hij verkeerde via zijn vrouw, de dichteres Cornelia Pluvier, wel in dichterskringen. Vgl. H.E. van Gelder, 'Aantekeningen over Willem Kalf en Cornelia Pluvier,' Oud Holland 59 (1942), pp. 37-46.

58 Vanuit dit perspectief geredeneerd is het misschien aannemelijker dat met Blom decoratie- en portretschilder Matheus Bloem bedoeld werd, dan Jan Blom, schilder van landschappen en stillevens.

59 $\operatorname{Adg} \mathrm{I}($ noot 4), p. 785 . Lievens tekening van Vos werd waarschijnlijk rond 1660 gemaakt en bevindt zich nu in Frankfurt, Städel Museum am Main; zie A.K. Wheelock jr. et al. (eds.), Jan Lievens. A Dutch Master Rediscovered, Washington, New Haven en London 2009, p. 258. Het portret van Du Jardin, een ets, lijkt speciaal vervaardigd voor Alle de gedichten en is daar ook in opgenomen, met een bijschrift van Vondel. Over dit portret: J.M. Kilian, The Paintings of Karel Du Jardin $1626-1678$. Catalogue Raisonné, Amsterdam en Philadelphia 2005, pp. 44-45.
60 Het portret dat Jan Lievens van Joanna Six schilderde is niet bewaard gebleven, vgl. S.S. Dickey, Rembrandt: portraits in print, Amsterdam 2004, p. 135. Een portret van Constancy Reynst door Bartholomeus van der Helst heb ik ook niet terug kunnen vinden.

6I Lievens wordt, naast de portretdichten bij de portretten van Johanna Six en Vos zelf, negen keer genoemd in titels, Quellinus zeven keer. De gedichtjes voor Quellinus staan in $A d g$ I (noot 4), pp. 352 en 553-554. Quellinus wordt bovendien geprezen in een gedicht voor Flinck: $\operatorname{Adg}$ I (noot 4), pp. 524-525.

$62 \operatorname{AdgI}($ noot 4), pp. 186, 720, 524 525 .

$63 A d g$ I (noot 4), pp. 613 en 528 . Het zou kunnen dat Vos nog meer gedichten voor Flinck geschreven heeft: er is een aantal puntgedichten aan 'G.F.' en die initialen komen ook voor in titels van beeld- en portretgedichten.

64 Hierover: S.A.C. Dudok van Heel, 'Het 'Schilderhuis' van Govert Flinck en de kunsthandel van Uylenburgh aan de Lauriergracht te Amsterdam', Jaarboek Amstelodamum 74 (1982), pp. 70-90.

65 Over Flincks positie in Amsterdamse regentenkringen recent: Erna Kok, 'Zonder vrienden geen carrière. De succesvolle loopbanen van de zeventiendeeeuwse kunstenaars Govert Flinck en Ferdinand Bol', De zeventiende eeuw 27 (2011) 2, pp. 300-336, m.n. pp. 309, 327-332. Over Lievens positie: Jaap van der Veen, 'Patronage for Lievens' portraits and history pieces, 1644-1674', in: Wheelock 2009 (noot 59), pp. 28-39. Over Quellinus' rol in de Amsterdamse kunstwereld bijvoorbeeld: Ch. Theuerkauff, 'Enkele kanttekeningen bij Artus Quellinus en de 'antiche Academien", Bulletin van het Rijksmuseum 50 (2002) 2, pp. 309-319.

66 Over de zelfportretten van Flinck: C.J. Bruyn-Kops, 'Vergeten zelfportretten van Govert Flinck en

Bartholomeus van der Helst', Bulletin van het Rijksmuseum 13 (1965), pp. 20-29, spec. pp. 27-29. Zie over het schuttersstuk en Vos' gedichtje daarop hierboven. Flincks hoofd staat op het schilderij direct boven dat van Huydecoper, aan de rechterkant.

67 J. Vos, Inwijding van het Stadthuis t'Amsterdam, Amsterdam: Jacob Lescaille, 1655 . Zie over dit gedicht: Geerdink 20I2 (noot 6), pp. I43, 194-196.

68 T. van Domselaer (red.), Hollantsche Parnas, of verscheide gedichten, gerijmt door J.

Westerbaen, J. v. Vondel, J. Vos., G. Brant, R. Anslo, en andere voornaamste dichters onzer eeuwe, Amsterdam 1660. Zie hierover Geerdink 2012 (noot 6), pp. 26, 184 .

\section{SUMMARY}

The poetry by Jan Vos (Amsterdam, 1610-1667) is known for its focus on the arts. Scholars have claimed that this was out of Vos's personal interest and that he was on friendly terms with many painters. This article argues that Vos's poetic concern with the arts is rather a consequence of his relationship of patronage with the Amsterdam city regents. This appears from an analysis of Vos's epigrams about portraits and other paintings; an analysis of the long epic poem Strydt tusschen de Doodt en Natuur, of Zeege der Schilderkunst (1654); and of the poems in which Vos addresses individual painters. 